Article

\title{
Constituents Isolated from the Leaves of Glycyrrhiza uralansis and Their Anti-Inflammatory Activities on LPS-Induced RAW264.7 Cells
}

\author{
Liyao Wang ${ }^{1}$, Kaixue Zhang ${ }^{1}$, Shu Han ${ }^{2}$, Liu Zhang ${ }^{1}$, Haiying Bai ${ }^{1}$, Fang Bao ${ }^{1}$, Yan Zeng ${ }^{3}$, \\ Jiyong Wang ${ }^{3}$, Hong Du ${ }^{2}$, Yingqian Liu ${ }^{1}$ and Zhigang Yang ${ }^{1, *}$ \\ 1 School of Pharmacy, Lanzhou University, LanZhou 730000, China; lywang17@lzu.edu.cn (L.W.); \\ zhangkx2018@lzu.edu.cn (K.Z.); zhangliu17@lzu.edu.cn (L.Z.); baihy14@lzu.edu.cn (H.B.); \\ baof16@lzu.edu.cn (F.B.); yqliu@lzu.edu.cn (Y.L.) \\ 2 School of Chinese Materia Medica, Beijing University of Chinese Medicine, Beijing 100029, China; \\ hs361015@163.com (S.H.); duhong@vip.163.com (H.D.) \\ 3 China National Traditional Chinese Medicine Co., Ltd., Beijing 100035, China; zyzy1221@126.com (Y.Z.); \\ wangjiyong75@163.com (J.W.) \\ * Correspondence: yangzg@lzu.edu.cn; Tel.: +86-931-8915202
}

Received: 23 April 2019; Accepted: 17 May 2019; Published: 18 May 2019

\begin{abstract}
Licorice, the root and rhizome of Glycyrrhiza uralansis Fisch, is one of the most frequently used Traditional Chinese Medicines in rigorous clinical trials to remove toxins and sputum, and to relieve coughing. However, the aerial parts are not used so widely at present. It has been reported that the aerial parts have many bioactivities such as anti-microbial and anti-HIV activities. In this study, we aimed to discover the bioactive compounds from the leaves of G. uralensis. Four new compounds, licostilbene A-B (1-2) and licofuranol A-B (3-4), together with eight known flavonoids (5-12), were isolated and identified from the leaves of G. uralensis. Their structures were elucidated mainly by the interpretation of high-resolution electrospray mass spectrometry (HR-ESI-MS) and nuclear magnetic resonance (NMR) spectroscopic data. Compared with quercetin, which showed a 50\% inhibitory concentration $\left(\mathrm{IC}_{50}\right.$ ) value of $4.08 \mu \mathrm{g} / \mathrm{mL}$, compounds $1-9$ showed significant anti-inflammatory activities by inhibiting lipopolysaccharide (LPS)-induced nitric oxide (NO) production with $\mathrm{IC}_{50}$ values of $2.60,2.15,3.21,3.25,2.00,3.45,2.53,3.13$ and $3.17 \mu \mathrm{g} / \mathrm{mL}$, respectively. The discovery of these active compounds is important for the prevention and treatment of inflammation.
\end{abstract}

Keywords: Glycyrrhiza uralensis; licostilbene; licofuranol; anti-inflammatory activity

\section{Introduction}

Licorice is a perennial herb of the genus Glycyrrhiza, mainly distributed in Xinjiang, Gansu, Ningxia and Inner Mongolia in China. The application of licorice has permeated many fields, including food, tobacco, cosmetics, health products and pharmaceuticals [1]. The pharmacopoeia of the People's Republic of China contains G. uralensis, G. glabra and G. inflata as medicinal materials. Their roots and rhizomes are the medicinal parts, which mainly contain triterpenoids and flavonoids. To date, more than 400 compounds have been isolated from licorice [2]. It is reported that licorice shows significant efficacy in relieving coughing and asthma [3], hepatoprotective [4], anti-inflammatory [5], anti-virus [6], anti-ulcer [7] and anti-diabetes [8] activities.

The underground part of licorice has been used for the treatment of many diseases for a long time in China. The aerial parts of licorice are not widely used, usually resulting in the waste of resources. However, the aerial parts possess a high nutritional value [9]. Several compounds have been identified in the aerial parts, including 75 flavonoids, 16 dihydrostilbenes and 18 amino acids [10]. It has been reported 
that the aerial parts have numerous beneficial effects, such as anti-coagulation, anti-thrombosis [11], anti-oxidation [12,13], anti-prostatitis [14], anti-microbial [15] and other biological activities.

Inflammation is the body's stress feedback to noxious stimuli, tissue damage, and infections, leading to inflammatory diseases, such as infections, metabolic diseases, cancer and aging [16]. Macrophages are important immune cells and play an important role in the inflammatory process. NO is one of important inflammatory mediators secreted by macrophages [17], and excessive production of NO will lead to cell damage and tissue necrosis, promoting the occurrence of inflammatory diseases. Thus, the inhibition of NO production is important for the treatment of inflammation and complications.

In this study, we aimed to find the bioactive compounds from the leaves of G. uralensis. As a result, four new compounds (1-4), together with eight known compounds (5-12), were isolated and identified (Figure 1). In addition, compounds 1-9 showed stronger anti-inflammatory activities by suppressing NO production in RAW264.7 cells.

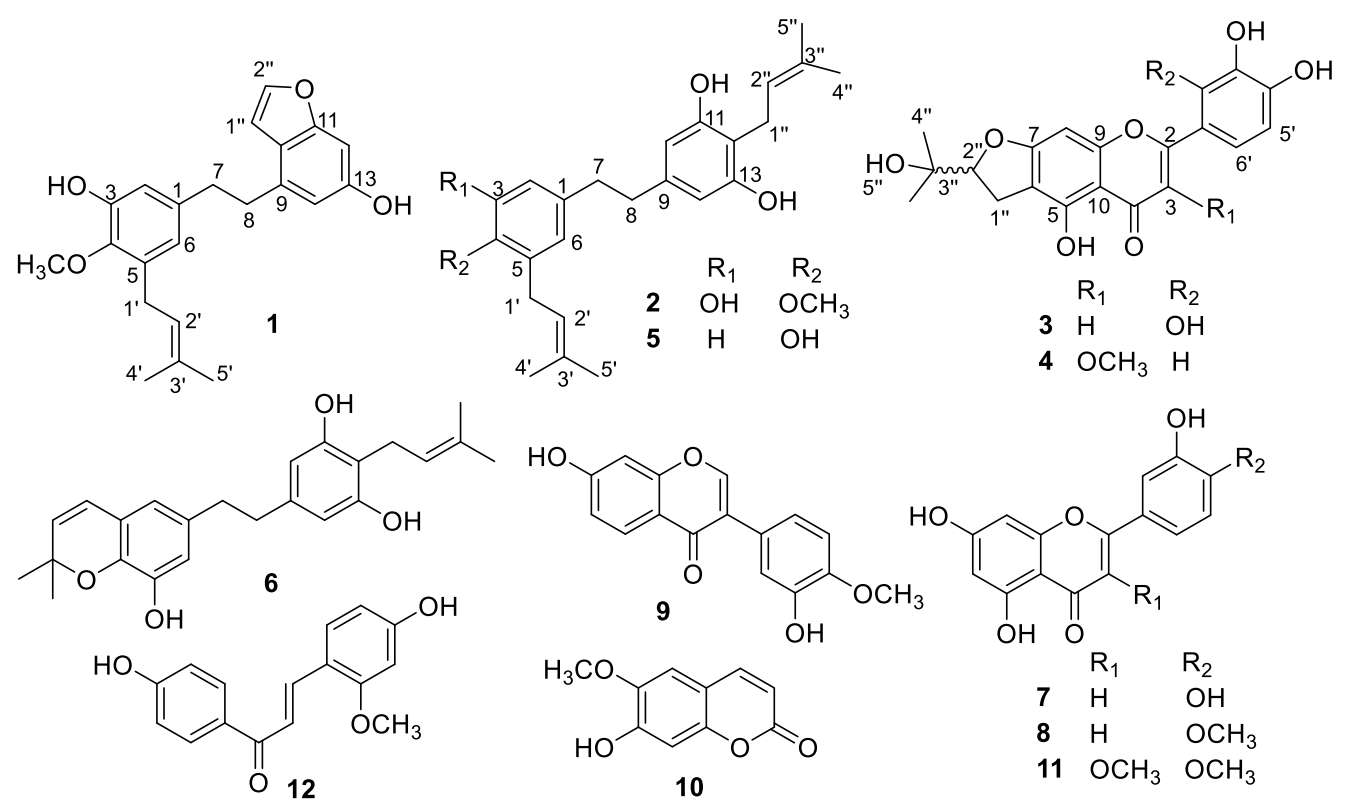

Figure 1. Structures of compounds 1-12 from G. uralensis.

\section{Results and Discussion}

\subsection{Identification of Compounds}

Compound $\mathbf{1}$ was obtained as a brown oil. The HR-ESI-MS date of $\mathbf{1}$ showed an $[\mathrm{M}+\mathrm{H}]^{+}$ion at $m / z 353.1742$, corresponding to a molecular formula of $\mathrm{C}_{22} \mathrm{H}_{24} \mathrm{O}_{4}$ (Figure $\mathrm{S} 3$, Supplementary Materials). The UV spectrum of $\mathbf{1}$ had absorption maxima at 250, 259 and $284 \mathrm{~nm}$, which indicated that $\mathbf{1}$ had an aromatic heterocyclic ring (Figure S2, Supplementary Materials).

The ${ }^{1} \mathrm{H}$-NMR spectrum (Figure S4, Supplementary Materials) showed four aromatic protons (Table 1). Two protons at $\delta_{\mathrm{H}} 6.58(1 \mathrm{H}, \mathrm{br} \mathrm{s})$ and $6.75(1 \mathrm{H}, \mathrm{d}, J=1.2 \mathrm{~Hz})$ displayed meta-coupling aryl moiety and other proton resonances at $\delta_{\mathrm{H}} 6.58(1 \mathrm{H}, \mathrm{br}$ s) and $6.43(1 \mathrm{H}, \mathrm{d}, J=1.6 \mathrm{~Hz})$ revealed one tetra-substituted benzene ring. Three signals at $\delta_{\mathrm{H}} 3.18(2 \mathrm{H}, \mathrm{d}, J=7.2 \mathrm{~Hz}), 5.11(1 \mathrm{H}, \mathrm{t}, J=7.2 \mathrm{~Hz})$ and $1.66(6 \mathrm{H}, \mathrm{s})$ were due to one prenyl group. The signals at $\delta_{\mathrm{H}} 6.83(1 \mathrm{H}, \mathrm{d}, J=1.2 \mathrm{~Hz})$ and $7.71(1 \mathrm{H}, \mathrm{d}$, $J=1.2 \mathrm{~Hz}$ ) were assigned to one benzofuran ring [18]. The signal of one methoxy group at $\delta_{\mathrm{H}} 3.64$ $(3 \mathrm{H}, \mathrm{s})$ was also observed. One hydroxy was assigned to C-3 according to the down-shifted chemical signal of C-3 at $\delta_{C} 149.7$ compared to that of 5 . In the analysis of ${ }^{13} \mathrm{C}-\mathrm{NMR}$ (Table 1), ${ }^{1} \mathrm{H}$-detected heteronuclear single quantum coherence (HSQC) and distortionless enhancement by polarization transfer (DEPT, Figures S5-S7, Supplementary Materials) spectra data revealed one methoxy at $\delta_{C} 59.6$, 
one prenyl at $\delta_{C} 28.3,123.4,134.3,25.5,17.6$, one tetra-substituted benzene ring at $\delta_{C} 114.5,119.7,135.0$, $149.7,143.7,134.3$ and one benzofuran ring at $\delta_{C} 105.1,143.4,118.6,136.9,116.7,155.4,95.4,155.38$.

Table 1. ${ }^{1} \mathrm{H}$ - and ${ }^{13} \mathrm{C}-\mathrm{NMR}$ spectroscopic data of compounds 1, 2 and 5 (400 MHz for ${ }^{1} \mathrm{H}-\mathrm{NMR}$ and $100 \mathrm{MHz}$ for ${ }^{13} \mathrm{C}-\mathrm{NMR}$, in DMSO- $d_{6}, \delta$ in ppm, $J$ in $\left.\mathrm{Hz}\right)$.

\begin{tabular}{|c|c|c|c|c|c|c|}
\hline \multirow{2}{*}{ Position } & \multicolumn{2}{|l|}{1} & \multicolumn{2}{|l|}{2} & \multicolumn{2}{|l|}{5} \\
\hline & $\delta_{H}$ & $\delta_{C}$ & $\delta_{H}$ & $\delta_{C}$ & $\delta_{H}$ & $\delta_{C}$ \\
\hline 1 & - & 135.0 & - & 137.1 & - & 131.8 \\
\hline 2 & $6.58(1 \mathrm{H}, \mathrm{s})$ & 114.5 & $6.54(1 \mathrm{H}, \mathrm{d}, J=1.6 \mathrm{~Hz})$ & 114.3 & $6.82(1 \mathrm{H}, \mathrm{d}, J=2 \mathrm{~Hz})$ & 129.2 \\
\hline 3 & - & 149.7 & - & 149.7 & - & 127.1 \\
\hline 4 & - & 143.7 & - & 143.6 & - & 152.9 \\
\hline 5 & - & 134.3 & - & 134.3 & $6.67(1 \mathrm{H}, \mathrm{d}, J=8.8 \mathrm{~Hz})$ & 114.7 \\
\hline 6 & $6.43(1 \mathrm{H}, \mathrm{d}, J=1.6 \mathrm{~Hz})$ & 119.8 & $6.40(1 \mathrm{H}, \mathrm{d}, J=1.6 \mathrm{~Hz})$ & 119.6 & $6.80(1 \mathrm{H}, \mathrm{dd}, J=8.8,2 \mathrm{~Hz})$ & 126.2 \\
\hline 7 & $2.73(2 \mathrm{H}, \mathrm{m})$ & 35.7 & $2.57(2 \mathrm{H}, \mathrm{m})$ & 36.5 & $2.62(2 \mathrm{H}, \mathrm{m})$ & 36.4 \\
\hline 8 & $2.93(2 \mathrm{H}, \mathrm{m})$ & 34.6 & $2.57(2 \mathrm{H}, \mathrm{m})$ & 37.1 & $2.54(2 \mathrm{H}, \mathrm{m})$ & 37.6 \\
\hline 9 & - & 136.9 & - & 139.6 & - & 139.7 \\
\hline 10 & - & 118.6 & $6.13(1 \mathrm{H}, \mathrm{s})$ & 106.2 & $6.12(1 \mathrm{H}, \mathrm{s})$ & 106.3 \\
\hline 11 & - & 155.4 & - & 155.7 & - & 155.7 \\
\hline 12 & $6.75(1 \mathrm{H}, \mathrm{d}, J=0.8 \mathrm{~Hz})$ & 95.4 & - & 111.7 & - & 111.7 \\
\hline 13 & - & 155.4 & - & 155.7 & - & 155.7 \\
\hline 14 & $6.58(1 \mathrm{H}, \mathrm{s})$ & 111.7 & $6.13(1 \mathrm{H}, \mathrm{s})$ & 106.2 & $6.12(1 \mathrm{H}, \mathrm{s})$ & 106.3 \\
\hline $1^{\prime}$ & $3.18(2 \mathrm{H}, \mathrm{d}, J=7.2 \mathrm{~Hz})$ & 28.3 & $3.19(2 \mathrm{H}, \mathrm{d}, J=7.2 \mathrm{~Hz})$ & 28.3 & $3.16(2 \mathrm{H}, \mathrm{d}, J=7.2 \mathrm{~Hz})$ & 28.2 \\
\hline $2^{\prime}$ & $5.16(1 \mathrm{H}, \mathrm{t}, J=7.2 \mathrm{~Hz})$ & 123.5 & $5.17(1 \mathrm{H}, \mathrm{m})$ & 123.5 & $5.24(1 \mathrm{H}, \mathrm{t}, J=7.2 \mathrm{~Hz})$ & 123.1 \\
\hline $3^{\prime}$ & - & 130.9 & - & 131.0 & - & 130.9 \\
\hline $4^{\prime}$ & $1.66(3 \mathrm{H}, \mathrm{s})$ & 17.7 & $1.67(3 \mathrm{H}, \mathrm{s})$ & 17.7 & $1.65(3 \mathrm{H}, \mathrm{s})$ & 17.7 \\
\hline $5^{\prime}$ & $1.66(3 \mathrm{H}, \mathrm{s})$ & 25.5 & $1.67(3 \mathrm{H}, \mathrm{s})$ & 25.5 & $1.67(3 \mathrm{H}, \mathrm{s})$ & 25.5 \\
\hline $1^{\prime \prime}$ & $6.83(1 \mathrm{H}, \mathrm{d}, J=2.0 \mathrm{~Hz})$ & 105.1 & $3.12(2 \mathrm{H}, \mathrm{d}, J=6.8 \mathrm{~Hz})$ & 21.9 & $3.12(2 \mathrm{H}, \mathrm{d}, J=6.8 \mathrm{~Hz})$ & 21.9 \\
\hline $2^{\prime \prime}$ & $7.71(1 \mathrm{H}, \mathrm{d}, J=2.0 \mathrm{~Hz})$ & 143.4 & $5.17(1 \mathrm{H}, \mathrm{m})$ & 123.9 & $5.15(1 \mathrm{H}, \mathrm{t}, J=6.8 \mathrm{~Hz})$ & 123.9 \\
\hline $3^{\prime \prime}$ & -1 & - & - & 129.0 & - & 129.0 \\
\hline $4^{\prime \prime}$ & - & - & $1.59(3 \mathrm{H}, \mathrm{s})$ & 17.7 & $1.59(3 \mathrm{H}, \mathrm{s})$ & 17.7 \\
\hline $5^{\prime \prime}$ & - & - & $1.68(3 \mathrm{H}, \mathrm{s})$ & 25.5 & $1.68(3 \mathrm{H}, \mathrm{s})$ & 25.5 \\
\hline $4-\mathrm{OCH}_{3}$ & $3.64(3 \mathrm{H}, \mathrm{s})$ & 59.6 & $3.64(3 \mathrm{H}, \mathrm{s})$ & 59.6 & & \\
\hline
\end{tabular}

The prenyl group in compound 1 was linked to $C-5\left(\delta_{C} 134.3\right)$, which was confirmed by the ${ }^{1} \mathrm{H}$-detected heteronuclear multiple bond correlation (HMBC) correlations (Figure S8, Supplementary Materials) of H-1' $\left(\delta_{\mathrm{H}} 3.18\right)$ with $\mathrm{C}-5\left(\delta_{\mathrm{C}} 134.3\right), \mathrm{C}-4\left(\delta_{\mathrm{C}} 143.7\right)$, and C-6 $\left(\delta_{\mathrm{C}} 119.8\right)$. The methoxy group was attached to $\mathrm{C}-4$ according to the $\mathrm{HMBC}$ correlations of $\delta_{\mathrm{H}} 3.64\left(-\mathrm{OCH}_{3}\right)$ with $4-\mathrm{OCH}_{3}\left(\delta_{\mathrm{C}} 59.6\right)$. The connection of the benzofuran ring to C-8 was clearly proved by HMBC correlations of $\mathrm{H}-8\left(\delta_{\mathrm{H}} 2.93\right)$ with C-10 $\left(\delta_{\mathrm{C}} 118.6\right)$ and $\mathrm{C}-14\left(\delta_{\mathrm{C}} 111.7\right)$, of $\mathrm{H}-12\left(\delta_{\mathrm{H}} 6.75\right)$ of $\mathrm{C}-10\left(\delta_{\mathrm{C}} 118.6\right), \mathrm{C}-11\left(\delta_{\mathrm{C}} 155.4\right)$ and C-14 $\left(\delta_{C} 111.7\right)$. Other correlations, such as $\mathrm{H}-7\left(\delta_{\mathrm{H}} 2.73\right)$ with $\mathrm{C}-1\left(\delta_{\mathrm{C}} 135.0\right), \mathrm{C}-6\left(\delta_{\mathrm{C}} 119.8\right)$ and $\mathrm{C}-8\left(\delta_{\mathrm{C}} 34.6\right)$, H-6 $\left(\delta_{\mathrm{H}} 6.43\right)$ with C-2 $\left(\delta_{C} 114.5\right), C-4\left(\delta_{C} 143.7\right)$ and C-7 $\left(\delta_{C} 35.7\right)$, provided further support for the confirmation of the structure. All of the above information determined that the structure of 1 was 3-hydroxy-1-(2-(3-hydroxy-4-methoxy-5-(3-methyl-2-butenyl)-phenyl)-ethyl) benzofuran, denoted as licostilbene A.

Compound 2 was obtained as brown oil and had the molecular formula $\mathrm{C}_{25} \mathrm{H}_{32} \mathrm{O}_{4}$, as inferred from the HR-ESI-MS in positive mode $[\mathrm{M}+\mathrm{H}]^{+}$at $m / z 397.2362$ (calcd. for $\mathrm{C}_{25} \mathrm{H}_{32} \mathrm{O}_{4}, 397.2373$ ) (Figure S12, Supplementary Materials). The UV spectrum of 2 had absorption maxima at 270 and $282 \mathrm{~nm}$, which indicated that it had benzene rings (Figure S11, Supplementary Materials).

The A ring of 2 displayed the same proton and carbon signals as those of the A ring of $\alpha, \alpha^{\prime}$-dihydro-3,5,4'-trihydroxy-4,5'-diisopentenylstilbene (5), and the B ring of 2 was the same as the C ring of licostilbene A (1) (Table 1). The ${ }^{1} \mathrm{H}-\mathrm{NMR}$ spectrum (Figure S13, Supplementary Materials) showed four aromatic proton resonances at $\delta_{\mathrm{H}} 6.54(1 \mathrm{H}, \mathrm{d}, J=1.6 \mathrm{~Hz}), 6.40(1 \mathrm{H}, \mathrm{d}, J=1.6 \mathrm{~Hz})$ and 6.13 $(2 \mathrm{H}, \mathrm{s})($ Table 1$)$. The signal at $\delta_{\mathrm{H}} 3.64(3 \mathrm{H}, \mathrm{s})$ was assigned to one methoxy group. Signals at $\delta_{\mathrm{H}} 1.59(3 \mathrm{H}$, s) $1.67(6 \mathrm{H}, \mathrm{s}), 1.68(3 \mathrm{H}, \mathrm{s}), 3.19(2 \mathrm{H}, \mathrm{d}, J=7.2 \mathrm{~Hz}), 3.12(2 \mathrm{H}, \mathrm{d}, J=7.2 \mathrm{~Hz})$ and $5.17(2 \mathrm{H}, \mathrm{m})$ were due to two prenyl groups. One signal at $\delta_{\mathrm{H}} 2.57(4 \mathrm{H}, \mathrm{m})$ was due to two methylenes. The ${ }^{13} \mathrm{C}-\mathrm{NMR}$ (Table 1), HSQC and DEPT (Figures S14-S16, Supplementary Materials) spectra of 2 displayed 25 carbon signals, including four methyls, one methoxy group, four methylenes and six methines. HMBC correlations showed correlations of $\mathrm{H}-1^{\prime}\left(\delta_{\mathrm{H}} 3.19\right)$ with $\mathrm{C}-4\left(\delta_{\mathrm{C}} 143.6\right), \mathrm{C}-5\left(\delta_{\mathrm{C}} 134.3\right), \mathrm{C}-6\left(\delta_{\mathrm{C}} 119.6\right), \mathrm{C}-2^{\prime}\left(\delta_{\mathrm{C}} 123.5\right)$ 
and C-3' $\left(\delta_{\mathrm{C}} 131.0\right)$, of H-7 $\left(\delta_{\mathrm{H}} 2.57\right)$ with $\mathrm{C}-2\left(\delta_{\mathrm{C}} 114.3\right)$ and $\mathrm{C}-6\left(\delta_{\mathrm{C}} 119.6\right)$, of H-1" $\left(\delta_{\mathrm{H}} 3.12\right)$ with C-11 $\left(\delta_{C} 155.3\right), C-13\left(\delta_{C} 155.3\right), C-2^{\prime \prime}\left(\delta_{C} 123.9\right)$ and C-3' ${ }^{\prime \prime}\left(\delta_{C} 129.0\right)$, of H-2' ${ }^{\prime}\left(\delta_{H} 5.17\right)$ with C- $4^{\prime \prime}\left(\delta_{C} 17.7\right)$ and $C-5^{\prime \prime}\left(\delta_{C} 25.5\right)$ (Figure S17, Supplementary Materials). On the basis of the above inferences, the structure of 2 was identified as 7,8-dihydro-3,11,13-trihydroxy-4-methoxy-5,12-diisopentenylstilbene and named as licostilbene $B$.

Compound 3 was found to be brown powder. The HR-ESI-MS spectrum of 3 gave a molecular ion peak $[\mathrm{M}+\mathrm{H}]^{+}$at $m / z 387.1068$, consistent with a molecular formula of $\mathrm{C}_{20} \mathrm{H}_{18} \mathrm{O}_{8}$ (Figure S21, Supplementary Materials). The configuration at C-2" was identified to be $R$ based on its optical rotation value $\left([\alpha]_{22} D+0.8\right.$, dissolved in methanol) [19]. The UV spectrum of 3 showed absorption maxima at 258 and $369 \mathrm{~nm}$, which indicated that compound 3 had a flavonoid skeleton [20] (Figure S20, Supplementary Materials).

The ${ }^{1} \mathrm{H}-\mathrm{NMR}$ spectrum (Table 2, Figure S22, Supplementary Materials) of compound 3 showed the presence of four aromatic protons, with two of them at $\delta_{\mathrm{H}} 6.89(1 \mathrm{H}, \mathrm{d}, J=8.8 \mathrm{~Hz})$ and $7.85(1 \mathrm{H}, \mathrm{d}$, $J=8.8 \mathrm{~Hz}$ ) assignable to a $2^{\prime}, 3^{\prime}, 4^{\prime}$-trihydroxy-substituted $\mathrm{B}$ ring of a flavone structure and two additional signals at $\delta_{\mathrm{H}} 7.69(1 \mathrm{H}, \mathrm{s})$ and $6.52(1 \mathrm{H}, \mathrm{s})$ assignable to the protons on C-3 and C-8 [21]. The signal at $\delta_{\mathrm{H}}$ $9.44\left(3 \mathrm{H}\right.$, br s) was due to three hydroxys connected with $\mathrm{C}-2^{\prime}, \mathrm{C}-3^{\prime}$ and $\mathrm{C}-4^{\prime}$. The signals at $\delta_{\mathrm{H}} 1.15(3 \mathrm{H}$, $\mathrm{s})$ and $1.14(3 \mathrm{H}, \mathrm{s})$ were due to two methoxy groups. The proton resonance at $\delta_{\mathrm{H}} 3.05(2 \mathrm{H}, \mathrm{d}, J=8.4 \mathrm{~Hz})$ and $4.74(1 \mathrm{H}, \mathrm{t}, J=8.4 \mathrm{~Hz})$ was due to an oxygenated methine and a methylene. One hydroxy $\left(\delta_{\mathrm{H}}\right.$ 12.76) was attached to $C-5(\delta 154.8)$ because of the intramolecular hydrogen bond which increased the chemical shift. The ${ }^{13}$ C-NMR (Table 2), HSQC and DEPT (Figures S23-S25, Supplementary Materials) spectra showed 20 carbon signals, with 15 of them assignable to a flavone skeleton and the remaining five carbons at $\delta_{C} 25.9,25.0,25.8,70.1$ and 91.5 assignable to a modified prenyl group.

Table 2. ${ }^{1} \mathrm{H}$ - and ${ }^{13} \mathrm{C}-\mathrm{NMR}$ spectroscopic data of compounds 3-4 (400 MHz for ${ }^{1} \mathrm{H}-\mathrm{NMR}$ and $100 \mathrm{MHz}$ for ${ }^{13} \mathrm{C}-\mathrm{NMR}$, in DMSO- $d_{6}, \delta$ in ppm, $J$ in $\mathrm{Hz}$ ).

\begin{tabular}{|c|c|c|c|c|}
\hline \multirow{2}{*}{ Position } & \multicolumn{2}{|l|}{3} & \multicolumn{2}{|l|}{4} \\
\hline & $\delta_{\mathbf{H}}$ & $\delta_{C}$ & $\delta_{\mathbf{H}}$ & $\delta_{C}$ \\
\hline 2 & - & 147.8 & - & 155.6 \\
\hline 3 & $7.69(1 \mathrm{H}, \mathrm{s})$ & 115.6 & - & 137.7 \\
\hline 4 & - & 176.0 & - & 178.1 \\
\hline 5 & - & 154.8 & - & 155.3 \\
\hline 6 & - & 108.4 & - & 108.8 \\
\hline 7 & - & 166.2 & - & 166.3 \\
\hline 8 & $6.52(1 \mathrm{H}, \mathrm{s})$ & 88.4 & $6.52(1 \mathrm{H}, \mathrm{s})$ & 88.6 \\
\hline 9 & - & 156.1 & - & 156.3 \\
\hline 10 & - & 103.9 & - & 105.1 \\
\hline $1^{\prime}$ & - & 119.9 & - & 120.5 \\
\hline $2^{\prime}$ & - & 146.9 & $7.55(1 \mathrm{H}, \mathrm{d}, J=1.6 \mathrm{~Hz})$ & 115.5 \\
\hline $3^{\prime}$ & - & 135.8 & - & 145.3 \\
\hline $4^{\prime}$ & - & 145.1 & - & 148.8 \\
\hline $5^{\prime}$ & $6.88(1 \mathrm{H}, \mathrm{d}, J=8.8 \mathrm{~Hz})$ & 115.2 & $6.91(1 \mathrm{H}, \mathrm{d}, J=8.4 \mathrm{~Hz})$ & 115.7 \\
\hline $6^{\prime}$ & $7.54(1 \mathrm{H}, \mathrm{d}, J=8.8 \mathrm{~Hz})$ & 122.0 & $7.44(1 \mathrm{H}, \mathrm{dd}, J=1.6,8.4 \mathrm{~Hz})$ & 120.8 \\
\hline $1^{\prime \prime}$ & $3.06(2 \mathrm{H}, \mathrm{d}, J=8.4 \mathrm{~Hz})$ & 25.8 & $3.05(2 \mathrm{H}, \mathrm{d}, J=8.4 \mathrm{~Hz})$ & 25.8 \\
\hline $2^{\prime \prime}$ & $4.73(1 \mathrm{H}, \mathrm{t}, J=8.4 \mathrm{~Hz})$ & 91.5 & $4.74(1 \mathrm{H}, \mathrm{t}, J=8.4 \mathrm{~Hz})$ & 91.6 \\
\hline $3^{\prime \prime}$ & - & 70.1 & - & 70.1 \\
\hline $4^{\prime \prime}, 5^{\prime \prime}$ & $1.16,1.14(6 \mathrm{H}, \mathrm{d})$ & $25.0,25.9$ & $1.15,1.14(6 \mathrm{H}, \mathrm{d})$ & $24.9,25.9$ \\
\hline 3-OCH3 & - & - & $3.78(3 \mathrm{H}, \mathrm{s})$ & 59.7 \\
\hline $5-\mathrm{OH}$ & $12.76(1 \mathrm{H}, \mathrm{s})$ & - & $12.92(1 \mathrm{H}, \mathrm{s})$ & - \\
\hline
\end{tabular}

An - OCH- $\mathrm{CH}_{2}-$ spin system was evident in the ${ }^{1} \mathrm{H}-\mathrm{NMR}$ and ${ }^{1} \mathrm{H}-{ }^{1} \mathrm{H}$ correlation spectroscopy ( ${ }^{1} \mathrm{H}^{1}{ }^{1} \mathrm{H}$ COSY, Figure S28, Supplementary Materials). HMBC (Figure S26, Supplementary Materials) supported the correlations between the oxygenated methine and methylene protons of this spin system and the carbon resonances at $\delta 108.4$ and $\delta 166.2$, and thus, the presence of a furan ring was confirmed which is fused to the flavone moiety. The presence of two isolated methyl groups 
belonging to a hydroxyisopropyl moiety of the furan ring located next to the methine proton was evident from the peaks at $\delta_{\mathrm{H}} 1.14(3 \mathrm{H}, \mathrm{s})$ and $1.16(3 \mathrm{H}, \mathrm{s})$ and carbon signals at $\delta_{\mathrm{C}} 25.0$, and 25.9 in ${ }^{1} \mathrm{H}$ and ${ }^{13} \mathrm{C}-\mathrm{NMR}$ spectra. HMBC correlations within the furan ring led to the assigned structure of compound 3. In addition, $\mathrm{HMBC}$ provided support for the existence of a flavoniod skeleton, such as correlations of $\mathrm{H}-3\left(\delta_{\mathrm{H}} 7.69\right)$ with $\mathrm{C}-2\left(\delta_{\mathrm{C}} 147.8\right)$ and $\mathrm{C}-\mathrm{1}^{\prime}\left(\delta_{\mathrm{C}} 119.9\right)$, of H-6 $\left(\delta_{\mathrm{H}} 7.54\right)$ with C-2 $\left(\delta_{\mathrm{C}} 147.8\right)$, of $\mathrm{H}-8\left(\delta_{\mathrm{H}} 6.52\right)$ with $\mathrm{C}-6\left(\delta_{\mathrm{C}} 108.4\right), \mathrm{C}-7\left(\delta_{\mathrm{C}} 166.2\right), \mathrm{C}-9\left(\delta_{\mathrm{C}} 156.1\right)$ and $C-10\left(\delta_{C} 103.9\right)$. Thus, the structure of the new compound 3 was elucidated as $(R)-7-(2,3,4-$ trihydroxyphenyl)-4-hydroxy-2-(2-hydroxypropan-2-yl)-2,3-dihydrofuro(3,2-g)chromen-5- one and named as licofuranol A.

Compound 4 was obtained as yellow powder. The HR-ESI-MS spectrum of 4 gave a molecular ion peak $[\mathrm{M}+\mathrm{H}]^{+}$at $m / z 401.1221$ consistent with a molecular formula of $\mathrm{C}_{21} \mathrm{H}_{20} \mathrm{O}_{8}$ (Figure S30, Supplementary Materials). The configuration at C-2" was identified to be $S$ based on its optical rotation value $\left([\alpha]_{22} D-2.1\right.$, dissolved in methanol) [19]. The UV spectrum of 4 had absorption maxima at 259 and $354 \mathrm{~nm}$ (Figure S29, Supplementary Materials), which suggested that 4 had a flavonoid skeleton.

The ${ }^{1} \mathrm{H}-\mathrm{NMR}$ spectrum (Figure S31, Supplementary Materials) showed four aromatic protons (Table 2). Three proton resonances at $\delta_{\mathrm{H}} 7.55(1 \mathrm{H}, \mathrm{d}, J=1.6 \mathrm{~Hz}), \delta 7.44(1 \mathrm{H}, \mathrm{dd}, J=1.6 \mathrm{~Hz}, 8.4 \mathrm{~Hz})$ and $\delta_{\mathrm{H}} 6.91(1 \mathrm{H}, \mathrm{d}, J=8.4 \mathrm{~Hz})$ were observed and displayed a typical ABX system of ring B. The signals at $\delta_{\mathrm{H}} 1.15(3 \mathrm{H}, \mathrm{s}), 1.14(3 \mathrm{H}, \mathrm{s}), 3.05(2 \mathrm{H}, \mathrm{d}, J=8.4 \mathrm{~Hz})$ and $4.74(1 \mathrm{H}, \mathrm{t}, J=8.4 \mathrm{~Hz})$ were due to a modified prenyl group. The signal at $\delta_{\mathrm{H}} 3.78(3 \mathrm{H}, \mathrm{s})$ was assigned to one methoxy group. The resonance at $\delta_{\mathrm{H}} 6.52(1 \mathrm{H}, \mathrm{s})$ was assigned to H-8 of the A ring. The ${ }^{13} \mathrm{C}-\mathrm{NMR}$ (Table 2), HSQC and DEPT spectra (Figures S32-S34, Supplementary Materials) showed 21 carbon signals, including a flavone skeleton, a modified prenyl group and one methoxy group.

The structure of compound 4 was very similar to compound 3, except one proton attached with C-3 and one hydroxy attached with C-2' were replaced by one methoxy group and one proton, respectively. Two hydroxys were attached to C- $3^{\prime}$ and $\mathrm{C}-4^{\prime}$ according to HMBC (Figure S35, Supplementary Materials) correlations of $\mathrm{H}-2^{\prime}\left(\delta_{\mathrm{H}} 7.55\right)$ and $\mathrm{H}-5^{\prime}\left(\delta_{\mathrm{H}} 6.91\right)$ with $\mathrm{C}-1^{\prime}\left(\delta_{\mathrm{C}} 120.5\right)$, $C-3^{\prime}\left(\delta_{C} 145.3\right), C-4^{\prime}\left(\delta_{C} 148.7\right)$ and $C-3^{\prime}\left(\delta_{C} 145.3\right), C-4^{\prime}\left(\delta_{C} 148.7\right), C-6^{\prime}\left(\delta_{C} 120.8\right)$, respectively. The methoxy group was attached to $\mathrm{C}-3$ due to the correlation of $\delta 3.78_{\mathrm{H}}\left(-\mathrm{OCH}_{3}\right)$ with $\mathrm{C}-3\left(\delta_{\mathrm{C}} 137.7\right)$. On the basis of the above analysis, the structure of 4 was (S)-7-(3, 4-dihydroxyphenyl)-4-hydroxy3-methoxy-2-(2-hydroxypropan-2-yl)-2,3-dihydrofuro(3,2-g)chromen-5-one, name as licofuranol B.

The known compounds 5-12 were identified as $\alpha, \alpha^{\prime}$-dihydro-3,5, $4^{\prime}$-trihydroxy-4, $5^{\prime}$-diisopenteny lstilbene (5) [22], glycypytilbene B (6) [23], luteolin (7) [24], quercetin-3,4'-dimethyl ether (8) [25], calycosin (9) [26], scopoletin (10) [27], diosmetin (11) [28] and echinatin (12) [29], comparing their spectral information with published data in the literature.

\subsection{Assessment of Compounds 1-9 on Cellular Viability.}

To assess the cell viability of compounds 1-9, RAW264.7 cells were exposed to different concentrations of these compounds. The control group was treated with DMSO. As a result, incubation of cells with 1-9 for $24 \mathrm{~h}$ exerted no significant influence on cell viability (Figure 2). 


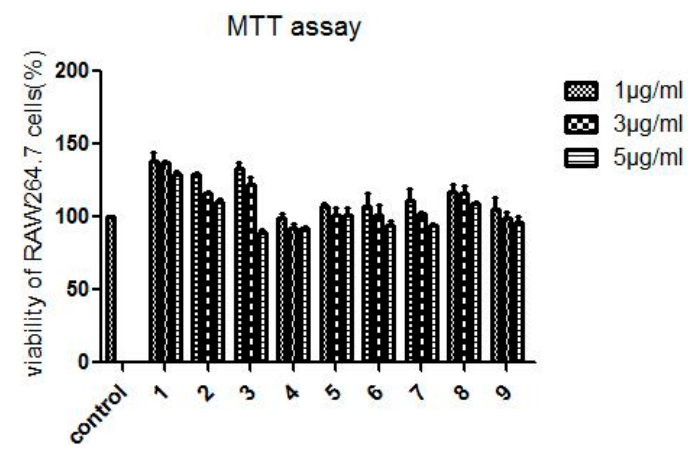

Figure 2. The cellular viabilities of RAW264.7 cells treated with compounds 1-9. All the data are expressed as means \pm SD of three independent experiments.

\subsection{Anti-Inflammatory Activity}

It has been reported that the extract of licorice suppresses LPS-induced inflammatory response in murine macrophage and increased the survival rate in LPS-induced mice macrophages [30]. In this work, the anti-inflammatory activity of compounds was evaluated in RAW264.7 cells with inflammation induced by LPS. Compounds $\mathbf{1} \mathbf{- 9}$ were tested for their NO inhibitory activities in the process of inflammation, and quercetin was used as a positive control. The anti-inflammatory activity of compounds 1-9 is shown in Table 3. As a result, four new compounds (1-4) and five known compounds (5-9) showed stronger anti-inflammatory activities than the positive control quercetin by inducing NO production on LPS-induced RAW264.7 cells.

Table 3. Effect of compounds 1-9 on NO production stimulated by LPS in RAW264.7 cells.

\begin{tabular}{cc}
\hline No. & $\mathrm{IC}_{\mathbf{5 0}}(\boldsymbol{\mu \mathrm { g }} / \mathrm{mL})$ \\
\hline $\mathbf{1}$ & 2.60 \\
$\mathbf{2}$ & 2.15 \\
$\mathbf{3}$ & 3.21 \\
$\mathbf{4}$ & 3.25 \\
$\mathbf{5}$ & 2.00 \\
$\mathbf{6}$ & 3.45 \\
$\mathbf{7}$ & 2.53 \\
$\mathbf{8}$ & 3.13 \\
$\mathbf{9}$ & 3.17 \\
quercetin & 4.08 \\
\hline
\end{tabular}

\section{Experimental}

\subsection{Materials and Methods}

\subsubsection{Plant Materials}

Fresh leaves of Glycyrrhiza uralensis were collected from Minqin County, Gansu Province, People's Republic of China, in September 2017. The plant was identified by one of the authors, Zhigang Yang, as the voucher specimen (No. MQG201610).

\subsubsection{Chemicals and Instruments}

Sephadex LH-20 was purchased from GE Healthcare Bio-Sciences AB (Uppsala, Sweden). The silica gel for column chromatography and thin-layer chromatography was obtained from Qingdao Marine Chemical Company (Qingdao, China). Open column chromatography was also performed using ODS- $\mathrm{C}_{18}$ (Cosmosil $75 \mathrm{C}_{18}-\mathrm{OPN}$ ). The semipreparative HPLC system was carried out on an easysep-1050 system equipped with a single-wavelength detector which was purchased from Unimicro Technologies Co., Lid (Shanghai, China), and a Waters C18 column. ${ }^{1} \mathrm{H}-\mathrm{NMR},{ }^{13} \mathrm{C}-\mathrm{NMR}$, and 2D-NMR 
spectra were obtained on a Bruker AVANCE AV III-400 spectrometer (Karlsruhe, BW, Germany). HR-ESI-MS was run on an Agilent LCxLC-IM-QTOF-MS $(1290 \times 1290-6560)$ spectrometer (Palo Alto, CA, USA). Optical rotations were recorded on a Perkin-Elmer 341 polarimeter. UV spectra were obtained with a UV/visible spectrophotometer (Perkin-Elmer, Waltham, MA, USA).

\subsection{Extraction and Isolation}

Leaves of Glycyrrhiza uralensis were dried in the shade. Extraction was performed by maceration of dried leaves $(8 \mathrm{~kg})$ in $80 \%$ methanol $(80 \mathrm{~L})$ at room temperature in a conical flask. This process was repeated 3 times and the final extract was filtered. The extract was concentrated under vacuum at $40{ }^{\circ} \mathrm{C}$ on a rotary evaporator (IKA ${ }^{\circledR}$-Werke GmbH \& Co.KG, Freiburg, BW, Germany). Then, all of the extract (1196.5 g) was dissolved in water and mixed with trichloromethane, ethyl acetate and n-butyl alcohol in a separating funnel to obtain four layers. The ethyl acetate layer was subjected to silica gel (100-200 mesh) column chromatography by successive elution with different proportions of petroleum ether/ethyl acetate (100:0-0:100). The extract was separated into 9 fractions (fr.A-I) according to TLC spots.

Fr.G (10.88 g) was separated by a reverse phase silica gel column with different proportions of methanol/water (20:80-100:1) to obtain 8 fractions (fr.G1-G8). Fr. G2 was further purified by semipreparative HPLC (MeOH/ $\left.\mathrm{H}_{2} \mathrm{O}, 70: 30\right)$ to obtain scopoletin (10, $\left.2.0 \mathrm{mg}\right)$. Fr.G4 and Fr.G5 were subjected to silica gel column chromatography to obtain fr.G4A-H and fr.G5A-G, respectively. Fr.G4E was further purified by semipreparative $\mathrm{HPLC}\left(\mathrm{MeOH} / \mathrm{H}_{2} \mathrm{O} 53: 47\right)$ to obtain calycosin $(\mathbf{9}, 6.7 \mathrm{mg})$ and echinatin (12, $4.6 \mathrm{mg})$.

Luteolin $(7,5.1 \mathrm{mg})$ was obtained from fr.G4F by semipreparative HPLC (MeOH/ $\left.\mathrm{H}_{2} \mathrm{O} 58: 42\right)$. Fr.G5C was also further purified by semipreparative $\mathrm{HPLC}\left(\mathrm{MeOH} / \mathrm{H}_{2} \mathrm{O} 58: 42\right)$ to obtain diosmetin $(\mathbf{1 1}, 7.9 \mathrm{mg})$ and quercetin-3,4'-dimethyl ether $(\mathbf{8}, 4.2 \mathrm{mg})$. Fr.G5E was applied to the silica gel column and eluted with $\mathrm{CH}_{2} \mathrm{Cl}_{2} / \mathrm{MeOH}$ to obtain 4 fractions (fr.G5E1-4). The semipreparative HPLC of fr.G5E2 $\left(\mathrm{MeOH} / \mathrm{H}_{2} \mathrm{O} 60: 40\right)$ led to licofuranol A $(3,26.5 \mathrm{mg})$ and licofuranol B $(4,15.8 \mathrm{mg})$.

Fraction D (1.85 g) was fractionated on a silica gel column to obtain 6 fractions (fr. D1-6). fr.D5 was separated by silica gel chromatography and successively eluted with petroleum ether/acetone(100:0-0:100) to obtain 8 fractions (sub-fr.D5A-H). D5G was further purified by silica gel column chromatography $\left(\mathrm{MeOH} / \mathrm{H}_{2} \mathrm{O} 75: 25\right)$ to give four compounds including licostilbene $\mathrm{A}(\mathbf{1}, 18.5 \mathrm{mg})$, licostilbene $\mathrm{B}(\mathbf{2}, 8.9 \mathrm{mg})$, $\alpha, \alpha^{\prime}$-dihydro-3,5,4'-trihydroxy-4,5'-diisopentenylstilbene $(5,12.6 \mathrm{mg})$ and glycypytilbene $\mathrm{B}(\mathbf{6}, 28.4 \mathrm{mg})$.

\subsection{Anti-Inflammatory Activity}

\subsubsection{Cell Culture}

The RAW264.7 macrophage cell line was obtained from the National Infrastructure of Cell Line Resource, maintained in Dulbecco's modified Eagle medium (DMEM, 10\% fetal bovine serum, 1\% penicillin and streptomycin) and grown at $37^{\circ} \mathrm{C}$ in a humidified incubator containing $5 \% \mathrm{CO}_{2}$. DMEM was changed every two days and cells were subcultured when $80-90 \%$ confluency was reached.

\subsubsection{MTT Assay}

The viability of RAW264.7 cells in the presence of different concentrations of compounds $(\mathbf{1}, \mathbf{3}, \mathbf{5}$ $\mu \mathrm{g} / \mathrm{mL}$, dissolved in DMSO) was evaluated by MTT assay. Briefly, the cells $\left(1 \times 10^{5} \mathrm{cells} / \mathrm{mL}\right)$ were seeded into a 96-well plate. After $12 \mathrm{~h}$ incubation, compounds 1-9 with different concentrations were added into the wells and incubated for $24 \mathrm{~h}$. Following incubation, the medium was removed, and $20 \mu \mathrm{L}$ of MTT $(5 \mathrm{mg} / \mathrm{mL})$ was added into the wells and incubated for another $4 \mathrm{~h}$. Finally, $150 \mu \mathrm{L}$ of DMSO was added and the absorbance at $490 \mathrm{~nm}$ was determined using a microplate reader. 


\subsubsection{NO Determination}

RAW264.7 cells were seeded at $1 \times 10^{6} / \mathrm{mL}$ in 96-well culture plates for NO. Nitrite $\left(\mathrm{NO}_{2}{ }^{-}\right)$in the culture medium was measured as an indicator of $\mathrm{NO}$ production using the Griess reaction. All of the operation was according to the NO kit instructions. Briefly, the cells were separated into four groups: treated with DMSO (negative control), LPS $(1 \mu \mathrm{g} / \mathrm{mL}$, model), LPS + quercetin $(5 \mu \mathrm{g} / \mathrm{mL}$, positive control) and LPS + compounds with different concentrations (treatment group). All the agents were added at the same time, and the groups were treated for $24 \mathrm{~h}$. After treatment with various concentrations of compounds and quercetin, the supernatant of cells was mixed with an equal volume of Griess reagent, and the absorbance of the mixture was measured at $540 \mathrm{~nm}$. The experiments were repeated three times independently.

\section{Conclusions}

In this work, 12 compounds, including four new structures (1-4), were isolated and identified from leaves of G. uralensis. Among these compounds, 1-9 showed significant NO inhibitory activities on LPS-induced RAW264.7 cells. Four bioactive compounds, licostilbene A-B (1-2) and licofuranol A-B (3-4), were observed for the first time. We hope that these active compounds will be useful for the prevention and treatment of inflammation.

Supplementary Materials: The following data are available online: component percentages of compound 1-12 (Table S1), UV, HR-ESI-MS, 1D- and 2D-NMR spectra of compounds 1-9 (Figures S1-S42).

Author Contributions: Z.Y. conceived and designed the experiments. L.W. conducted the purification of the compounds and the structure elucidation. K.Z. and H.B. conducted and analyzed the HRESIMS analysis. L.Z. conducted and analyzed the UV analysis. S.H. and H.D. evaluated the anti-inflammatory activity of pure compounds. H.B., L.W., Y.Z. and J.W. collected the plant material. F.B. provided helps in the procedure of isolation. L.W., Z.Y., Y.L., K.Z. and L.Z. shared the processes of analyzing the data and writing the manuscript.

Funding: This work was supported by the grant from the Major International S \& T Cooperation Project, Ministry of Science and Technology of the People's Republic of China (2016YFE0129000; 2017YFC1701400; SQ2017YFC170424); Research project of Gansu Provincial Administration of Traditional Chinese Medicine (GZK-2015-21); the Key Program for International S\&T Cooperation Projects of Gansu Province (18YF1WA115); and the Fundamental Research Funds for the Central Universities (lzujbky-2017-k26).

Acknowledgments: The authors are thankful to the Analysis and Test Center, Lanzhou University; Lanzhou Institute of Chemical Physics, Chinese Academy of Sciences.

Conflicts of Interest: The authors declare no conflict of interest.

\section{References}

1. Kao, T.C.; Wu, C.H.; Yen, G.C. Bioactivity and Potential Health Benefits of Licorice. J. Agr. Food Chem. 2014, 62, 542-553. [CrossRef] [PubMed]

2. Bao, F.; Bai, H.Y.; Wu, Z.R.; Yang, Z.G. Phenolic compounds from cultivated Glycyrrhiza uralensis and their PD-1/PD-L1 inhibitory activities. Nat. Prod. Res. 2019, 25, 1-8. [CrossRef]

3. Kuang, Y.; Li, B.; Fan, J.; Qiao, X.; Ye, M. Antitussive and expectorant activities of licorice and its major compounds. Bioorgan. Med. Chem. 2018, 26, 278-284. [CrossRef]

4. Abdel-Kader, M.S.; Abulhamd, A.T.; Hamad, A.M.; Alanazi, A.H.; Ali, R.; Alqasoumi, S.I. Evaluation of the hepatoprotective effect of combination between hinokiflavone and Glycyrrhizin against $\mathrm{CCl}_{4}$ induced toxicity in rats. Saudi Pharm. J. 2018, 26, 496-503. [CrossRef] [PubMed]

5. Wang, X.; Hao, H.; Chu, L. Glycyrrhizin inhibits LPS-induced inflammatory mediator production in endometrial epithelial cells. Microb. Pathog. 2018, 109, 110-113. [CrossRef] [PubMed]

6. Fukuchi, K.; Okudaira, N.; Adachi, K.; Odai-Ide, R.; Sakagami, H. Antiviral and antitumor activity of licorice root extracts. In Vivo 2018, 30, 777-786. [CrossRef]

7. Liu, D.; Huo, X.; Gao, L.; Zhang, J.; Ni, H.; Cao, L. Nf-kb and Nrf2 pathways contribute to the protective effect of licochalcone a on dextran sulphate sodium-induced ulcerative colitis in mice. Biomed. Pharmacother. 2018, 102, 922-929. [CrossRef] [PubMed] 
8. Bai, M.; Yao, G.D.; Ren, Q.; Li, Q.; Liu, Q.B.; Zhang, Y.; Wang, X.B.; Huang, X.X.; Song, S.J. Triterpenoid saponins and flavonoids from licorice residues with anti-inflammatory activity. Ind. Crop. Prod. 2018, 125, 50-58. [CrossRef]

9. Wu, Q.; Cai, Q.; Liu, C.; Gao, Q.H.; Tao, X.J.; Fan, Y.N.; Yang, J.J. Analysis of Nutritional Components and Volatile Oil Components of Glycyrrhiza Leaves in Ningxia Region. Acta Nutr. Sinca 2018, 40, 619-621. [CrossRef]

10. Fan, Y.H. Isolation, Identification, Quantification and Bioactivity Assessment of the Chemical Constituents in Glycyrrhiza uralensis Leaves. Master' Thesis, Inner Mongolia University, Hohhot, China, June 2018.

11. Yang, Y.M.; Qin, J.M.; Xu, J.H. Effect of Total Flavones of Radix et Folium Glycyrrhizae on Thrombogenesis and Coagulation Time in Rats. J. Baotou Med. Coll. 2003, 19, 90-91. [CrossRef]

12. Siracusa, L.; Saija, A.; Cristani, M.; Cimino, F.; D'Arrigo, M.; Trombetta, D.; Rao, F.; Ruberto, G. Phytocomplexes from liquorice (Glycyrrhiza glabra L.) leaves - Chemical characterization and evaluation of their antioxidant, anti-genotoxic and anti-inflammatory activity. Fitoterapia 2011, 82, 546-556. [CrossRef] [PubMed]

13. Kang, X.F.; Li, H.L.; Wang, W.Q. Evaluation of the antioxidant activity of fat-soluble flavonoids in aerial parts of Glycyrrhiza uralensis Fisch. Glob. Trad Chin. Med. 2016, 9, 567-570. [CrossRef]

14. Deng, Y.M. Study on the Extraction Technology of Total Flavonoids and Potential Basis for Prostatitis from Glycyrrhiza Leaves. Master' Thesis, South-Central University for Nationalities, Wuhan, China, May 2008.

15. Manfredi, K.P.; Vallurupalli, V.; Dexnidova, M.; Kindscher, K.; KPannell, L. Isolation of an anti-HIV diprenylated bibenzyl from GLycyrrhiza Lepidota. Phytochemistry 2001, 58, 153-157. [CrossRef]

16. Xie, C.F.; Li, X.T.; Zhu, J.Y.; Wu, J.S.; Geng, S.S.; Zhong, C.Y. Magnesium isoglycyrrhizinate suppresses LPS-induced inflammation and oxidative stress through inhibiting NF-KB and MAPK pathways in RAW264.7 cells. Bioorgan. Med. Chem. 2019, 27, 516-524. [CrossRef]

17. Kongkatitham, V.; Muangnoi, C.; Kyokong, N.; Thaweesest, W.; Likhitwitayawuid, K.; Rojsitthisak, P.; Sritularak, B. Anti-oxidant and anti-inflammatory effects of new bibenzyl derivatives from Dendrobium parishii in hydrogen peroxide and lipopolysaccharide treated RAW264.7 cells. Phytochem. Lett. 2018, 24, 31-38. [CrossRef]

18. Yang, D.S.; Wei, J.G.; Peng, W.B.; Wang, S.M.; Sun, C.; Yang, Y.P.; Liu, K.C.; Li, X.L. Cytotoxic prenylated bibenzyls and flavonoids from Macaranga kurzii. Fitoterapia 2014, 99, 261-266. [CrossRef] [PubMed]

19. Won, T.H.; Song, I.H.; Kim, K.H.; Yang, W.Y. Bioactive Metabolites from the Fruits of Psoralea corylifolia. J. Nat. Prod. 2015, 78, 666-673. [CrossRef]

20. Boué, S.M.; Carter-Wientjes, C.H.; Shih, B.Y.; Cleveland, T.E. Identification of flavone aglycones and glycosides in soybean pods by liquid chromatography-tandem mass spectrometry. J. Chromatogr. A 2003, 991, 61-68. [CrossRef]

21. Zheng, Z.; Cheng, K.; To, J.; Li, H.; Wang, M. Isolation of tyrosinase inhibitors from Artocarpus heterophyllus and use of its extract as antibrowning agent. Mol. Nutr. Food Res. 2018, 52, 1530-1538. [CrossRef]

22. Biondi, D.M.; Rocco, C.; Ruberto, G. New dihydrostilbene derivatives from the leaves of Glycyrrhiza glabra and evaluation of their antioxidant activity. J. Nat. Prod. 2003, 66, 477-480. [CrossRef]

23. Ma, C.M.; Fan, Y.H.; Ye, R.G.; Xu, H.Y.; Feng, X.H. Preparation of Isopentenyl Dihydrostilbene and Isopentenyl Flavone for Treatment of Obesity, Diabetes, and Hepatic Fibrosis. Patent CN 108997296 A, 14 December 2018.

24. Fan, Q.; Zhang, Y.; Zhou, X.L.; Ge, S.S.L.; Huang, C. Study on Chemical Constituents of Codonopsis nervoa Chipp Nannf. Chin. Pharm. J. 2011, 46, 256-259.

25. Barberá, O.; Marco, J.A.; Sanz, J.F.; Sánchez-Parareda, J. 3-Methoxyflavones and coumarins from Artemisia incanescens. Phytochemistry 1986, 25, 2357-2360. [CrossRef]

26. Zhang, X.J.; Li, L.Y.; Norbo, K.; Wang, S.S.; Sheng, Q.; Chen, W.; Liang, H.; Zhao, W.W.; Zhang, Q.Y. Flavonoids from Tibetan medicine Oxytropis falcate Bunge. J. Chin. Pharm. Sci. 2014, 23, 99-105. [CrossRef]

27. Mo, D.J.; Li, M.Y. Chemical Constituents of Semi-Mangrove Plant Excoecaria agallocha L.. Nat. Prod. Res Dev. 2017, 29, 52-57. [CrossRef]

28. Blunder, M.; Orthaber, A.; Bauer, R.; Bucar, F.; Kunert, O. Efficient identification of flavones, flavanones and their glycosides in routine analysis via off-line combination of sensitive NMR and HPLC experiments. Food Chem. 2017, 218, 600-609. [CrossRef] 
29. Ji, S.; Li, Z.; Song, W.; Wang, Y.; Liang, W.; Li, K.; Tang, S.; Wang, Q.; Qiao, X.; Zhou, D.; et al. Bioactive Constituents of Glycyrrhiza uralensis (Licorice): Discovery of the Effective Components of a Traditional Herbal Medicine. J. Nat. Prod. 2016, 79, 281-292. [CrossRef]

30. Kim, J.K.; Oh, S.M.; Kwon, H.S.; Oh, Y.S.; Lim, S.S.; Shin, H.K. Anti-inflammatory effect of roasted licorice extracts on lipopolysaccharide-induced inflammatory responses in murine macrophages. Biochem. Bioph. Res. Commu. 2006, 345, 1215-1223. [CrossRef] [PubMed]

Sample Availability: Samples of the compounds are available from the authors.

(C) 2019 by the authors. Licensee MDPI, Basel, Switzerland. This article is an open access article distributed under the terms and conditions of the Creative Commons Attribution (CC BY) license (http://creativecommons.org/licenses/by/4.0/). 